Int. J. Dev. Biol. 48: 879-888 (2004)

doi: $10.1387 / \mathrm{ijdb} .0418891 \mathrm{r}$

\title{
Activated Ras induces lens epithelial cell hyperplasia but not premature differentiation
}

\author{
LIXING W. RENEKER ${ }^{*}, 1$, LEIKE XIE ${ }^{1}$, LI XU1 ${ }^{1}$, VENKATESH GOVINDARAJAN $\#, 2$ and PAUL A. OVERBEEK ${ }^{2}$ \\ ${ }^{1}$ Department of Ophthalmology, School of Medicine, University of Missouri, Columbia, Missouri, USA and \\ ${ }^{2}$ Department of Molecular and Cellular Biology, Baylor College of Medicine, One Baylor Plaza, Houston, Texas, USA
}

\begin{abstract}
Growth factor signaling is implicated in the regulation of lens cell proliferation and differentiation during development. Activation of growth factor receptor tyrosine kinases is known to activate Ras proteins, small GTP-binding proteins that function as part of the signal transduction machinery. In the present study, we examined which classical Ras genes are expressed in lens cells during normal development and whether expression of an activated version of Ras is sufficient to induce either lens cell proliferation or fiber cell differentiation in transgenic mice. In situ hybridization showed H-Ras, K-Ras and N-Ras are ubiquitously expressed in all cells of the embryonic (E13.5) eye, with N-Ras showing the highest level of expression. The expression level of $\mathrm{N}$-Ras decreases during later stages of embryonic development, and is nearly undetected in postnatal day 21 lenses. To generate transgenic mice, a constitutively active $\mathrm{H}$-Ras mutant was linked to a chimeric regulatory element containing the mouse $\alpha A$-crystallin promoter fused to the chick $\delta 1$-crystallin lens enhancer element. In the lenses of the transgenic mice, the transgene was expressed in both lens epithelial and fiber cells. Expression of activated Ras was sufficient to stimulate lens cell proliferation but not differentiation, implying that alternative or additional signal transduction pathways are required to induce fiber cell differentiation.
\end{abstract}

KEY WORDS: Ras, lens, oncogene, transgenic, development

\section{Introduction}

Cell proliferation and differentiation are precisely regulated during lens development (Jean et al., 1998; McAvoy et al., 1999; Chow and Lang, 2001; Menko, 2002). During lens induction, the lens placode invaginates to form the lens pit and subsequently the lens vesicle (Cvekl and Piatigorsky, 1996; McAvoy et al., 1999). Cells at the anterior of the lens vesicle become proliferative lens epithelial cells, while the posterior cells exit from the cell cycle, elongate into lens fiber cells and fill the lumen of the vesicle. Subsequent growth of the lens involves proliferation of the lens epithelial cells, particularly in the germinative zone. As the epithelial cells migrate to the lens equator, they are induced to differentiate into lens fiber cells and thus form the transitional zone. During differentiation, cells exit from the cell cycle, elongate and express fiber cell specific markers including $\beta$ - and $\gamma$ crystallins (Piatigorsky, 1981).

There is considerable evidence that growth factors influence lens cell proliferation and differentiation (Chamberlain et al., 1991; Potts et al., 1994; Robinson et al., 1995b; Reneker and Overbeek, 1996). Fibroblast growth factors (FGFs), for example, can induce lens epithelial cells to differentiate into fiber cells in both lens explants and in transgenic mice (Chamberlain and McAvoy, 1989; Lovicu and Overbeek, 1998; Le and Musil, 2001). Blocking FGF receptor (FGFR) activation in the lens, either by expressing a dominant negative form of FGFR1 or a secreted form of FGFR3, inhibits normal lens fiber cell differentiation and results in a smaller lens (Chow et al., 1995; Robinson et al., 1995a; Stolen and Griep, 2000; Govindarajan and Overbeek, 2001). Platelet-derived growth factor (PDGF) has also been shown to regulate lens growth (Reneker and Overbeek, 1996). PDGF-A and B isoforms are expressed in the eye by tissues close to the lens (Potts et al., 1994; Reneker and Overbeek, 1996). Furthermore, mice homozygous for mutations of the PDGF receptor $\alpha$ gene have reduced numbers of lens cells (Morrison-Graham etal., 1992). Insulin and insulin-like growth factors (IGFs) have been shown to induce fiber cell differentiation in chick lenses (Hyatt and Beebe, 1993) and to enhance fiber cell differentiation in a rat lens explant system

Abbreviations used in this paper:FGF, fibroblast growth factor; IGF, insulin -like growth factor; PDGF, platelet-derived growth factor.

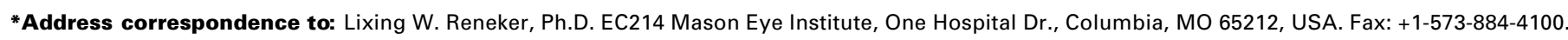
e-mail: renekerl@health.missouri.edu

\# Current address: Cancer Center, Creighton University, Omaha, Nebrasca, USA.
} 

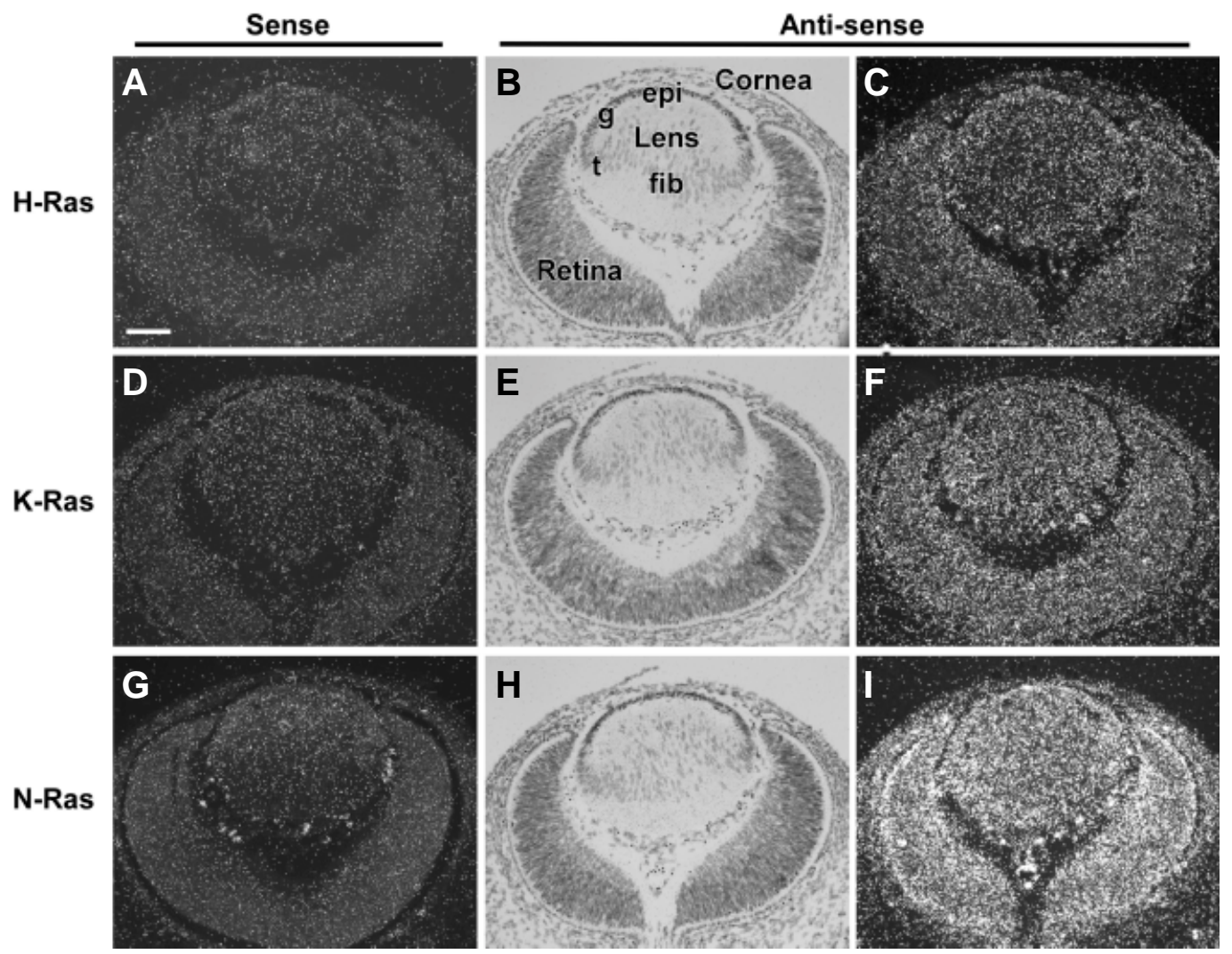

Fig. 1. $\boldsymbol{H}-, \boldsymbol{K}$ - and $\boldsymbol{N}$-Ras expression in $\mathbf{E} 13.5$ mouse eyes. Expression of $\mathrm{H}-(A-C), \mathrm{K}-(D-F)$ and $\mathrm{N}-(\mathrm{G}-\mathrm{I})$ Ras genes was detected by in situ hybridization using 35 S-labeled riboprobes. Sense probes $(\mathbf{A}, \mathbf{D}, \mathbf{G})$ for each Ras gene were used as negative controls to detect background signals. For antisense probes, sections are shown as bright-

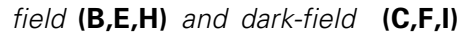
images. All three Ras genes appear to be ubiquitously expressed in the tissues of the embryonic eye. N-Ras (I) shows the strongest hybridization signal. The K-Ras probe used in this study can hybridize to both K-Ras4a and $\mathrm{K}-\mathrm{Ras} 4 \mathrm{~b}$, the two splice variants of the K-Ras gene (Barbacid, 1987). Scale bars represent $100 \mu \mathrm{m}$. The same abbreviations are used in all figures: epi, lens epithelium; fib, lens fiber cells; $g$, germinative zone; $t$, transitional zone.
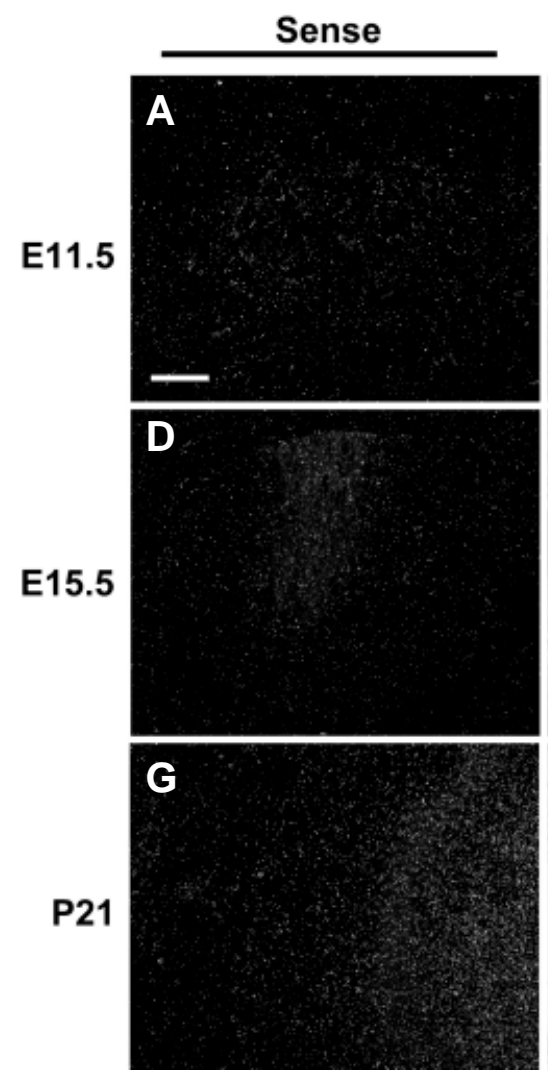
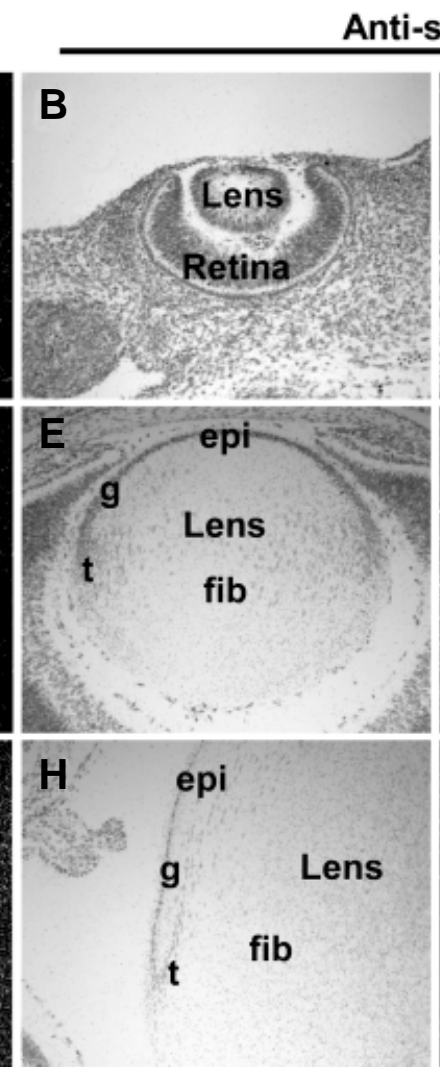
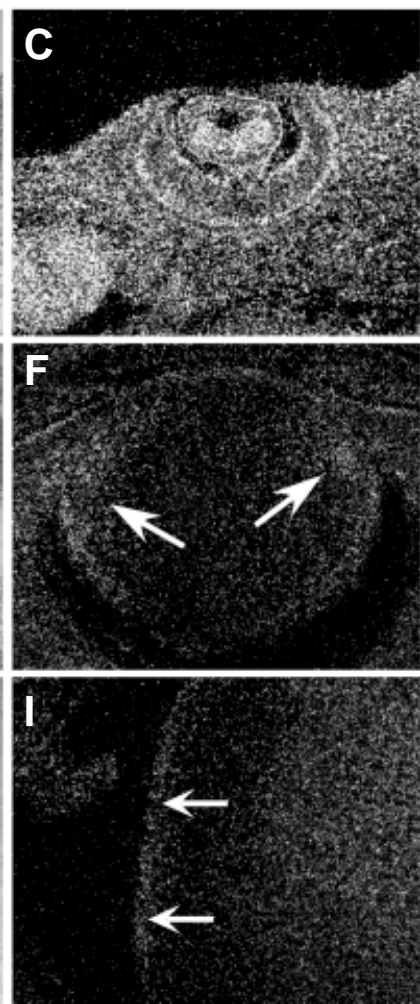

Fig. 2. N-Ras expression in mouse lenses at different ages. N-Ras expression in E11.5 (A-C), E15.5 (D-F) and P21 (G-I) lenses was examined by in situ hybridization. Dark-field images with the sense probe are shown in $(\mathbf{A}, \mathbf{D}, \mathbf{G})$. Brightfield (B,E,H) and matching darkfield images (C,F,I) are shown for the anti-sense probe. At E11.5, NRas is highly expressed in the eye including the lens and also in the surrounding head tissues. N-Ras expression is significantly downregulated in the E15.5 lens, but transcripts can still be detected (arrows in F). In the P21 lens, a low level of N-Ras mRNA was detected (arrows in I). 
(Richardson et al., 1993). Although different growth factors can stimulate lens epithelial cells, very little is known about the downstream signal transduction pathways in the lens. In the lens, growth factor receptors are expressed throughout development. PDGF receptor $\alpha$ is strongly expressed in the lens epithelial cells (Potts et al., 1994; Reneker and Overbeek, 1996). Among the four FGF receptor (FGFR) genes, the lens expresses FGFR1, FGFR2 (splice versions IIIb and IIIc) and FGFR3 (de longh et al., 1996; de longh et al., 1997).

The receptors for FGFs, PDGFs, and IGFs all have tyrosine kinase activity (Ullrich and Schlessinger, 1990; Heldin, 1995). Ligand binding induces autophosphorylation of tyrosine residues on these receptors as well as phosphorylation of other proteins (Ullrich and Schlessinger, 1990; Heldin, 1995). The phosphorylated tyrosine residues then serve as docking sites for numerous Src homology 2 ( $\mathrm{SH} 2$ )-domain containing proteins including adaptor protein Grb2. Grb2 can recruit the GTP-exchange factor Sos to activate Ras proteins, key molecules for signal transduction. Activated Ras proteins associate with multiple downstream effectors including the Raf-1/mitogen-activated protein kinase (MAPK) cascade, the small G proteins Rac and Rho, and phosphoinositide 3-kinase (PI3K) (Campbell etal., 1998; Downward, 2003). Through downstream signaling pathways such as these, Ras is thought to coordinate and regulate many aspects of cell behavior including cell proliferation, cell morphology and cell survival.

Although there is no direct evidence that Ras is essential for lens development, several studies have shown that MAPKs (also known as extracellular signal-regulated kinases or ERKs) may be involved in lens cell proliferation and differentiation (Le and Musil, 2001; Lovicu and McAvoy, 2001; Maidment et al., 2004). FGFs, EGF and insulin or IGF stimulate phosphorylation of ERKs in rodent, chick or human lens cells (Le and Musil, 2001; Lovicu and McAvoy, 2001; Maidment et al., 2004). In rat lens explants, inhibition of ERK signaling can block FGF-induced lens cell proliferation and some of the morphological changes associated with fiber cell differentiation (Lovicu and McAvoy, 2001). To date, the question of whether Ras activation is necessary or sufficient to stimulate lens cell proliferation or fiber cell differentiation, has not been addressed.

To explore the role(s) of Ras genes in the lens, we first assayed for expression of different Ras genes during normal mouse lens development. Next we generated and characterized transgenic mice that express a constitutively active human $\mathrm{H}$-Ras protein in the lens. Our results show 1 ) that N-Ras is the classical Ras gene expressed at the highest levels during early lens development, and 2) that Ras activation is sufficient to induce lens cell proliferation but not differentiation. Therefore, alternative or additional signal transduction pathways are likely to be required for lens fiber cell differentiation.

\section{Results}

We analyzed the expression of three classical Ras genes: H-Ras, K-Ras and N-Ras (Barbacid, 1987) during lens development. By RTPCR, all three Ras genes were found to be expressed in the perinatal mouse lens (data not shown). The RT-PCR products were cloned and used as riboprobes for in situ hybridizations. Hybridization signals were detected for all three genes in both lens epithelial and fiber cells at embryonic day 13 (E13) (Fig. 1). N-Ras was expressed at a higher level than the other two genes (Fig. 1).
Lens growth rate slows down during the course of embryonic and postnatal development. To investigate whether N-Ras expression also changes during lens development, we performed
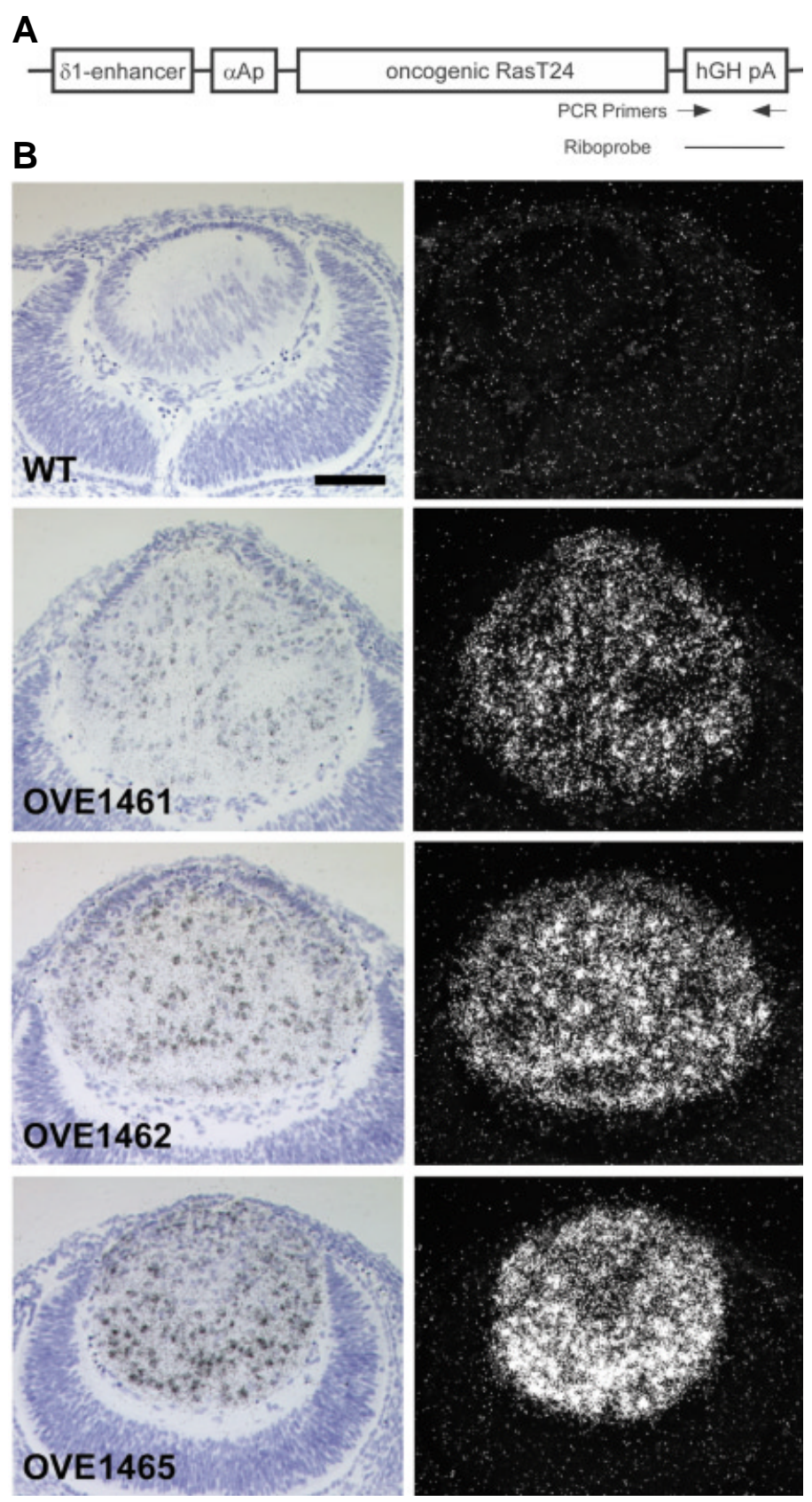

Fig. 3. Transgene expression in E12.5 lenses. (A) Diagram of the Ras minigene used for microinjections. The chick $\delta 1$-crystallin lens-enhancer element ( $\delta 1$-enhancer) was added to the $5^{\prime}$ end of the mouse $\alpha A$-crystallin promoter $(\alpha A p)$. The human growth hormone polyadenylation signal (hGH pA) was added to the $3^{\prime}$ end of the RasT24 sequences. PCR primers homologous to the $h \mathrm{GH}$ sequences are used for genotyping the transgenic mice. (B) Detection of Ras transgene expression in E12.5 lenses isolated from different transgenic families (OVE1461, OVE1462 and OVE1465). In situ hybridization was done using a riboprobe corresponding to the $h \mathrm{GH}$ sequences of the minigene (shown in A). Bright field images are shown on the left and the matching dark field images on the right. No signal was detected in the non-transgenic (WT) lens. In each family, transgene expression was detected in all the lens cells. 

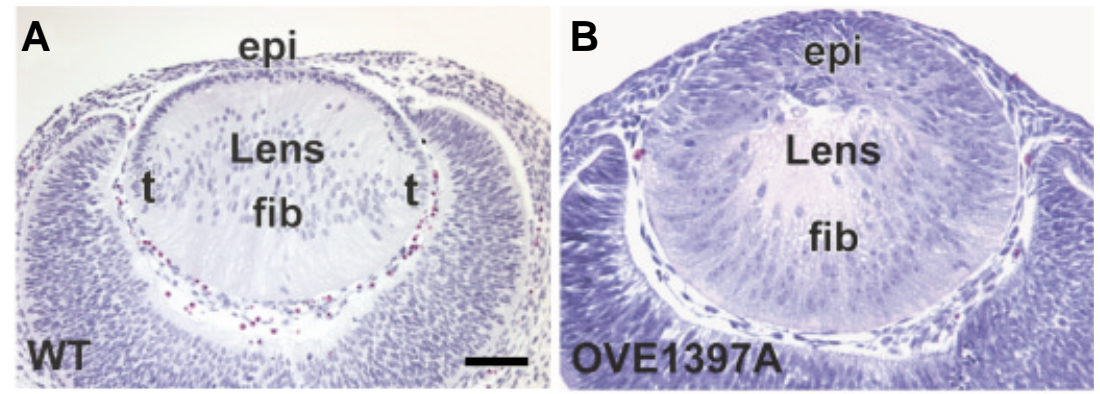

expression level of $\mathrm{N}$-Ras correlates with the lens growth rate.

To alter the level of Ras activity during lens development, we generated transgenic micethat express a constitutively active Ras mutant (rasT24) in the lens (Fig. 3A). RasT24 was linked to the mouse $\alpha$ A-crystallin promoter which was fused to the chick $\delta 1$-crystallin enhancer (Hayashi et al., 1987). This chimeric $\delta e n \alpha A$ regulatory element is a lens-specific promoter that is capable of directing transgene expression in both lens
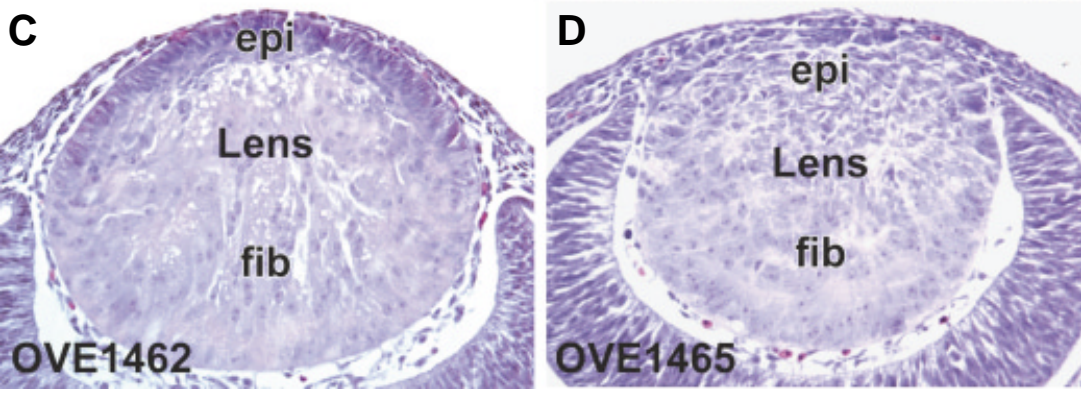
epithelial and fiber cells (Reneker et al, 2004). Using this minigene, we generated ten transgenic founder mice. The offspring of one founder mouse showed variable phenotypes. Southern blot analysis revealed the presence of three different integration sites in the founder mouse that were segregating in the F1 generation (data not shown). Three subfamilies were established from this founder and designated as OVE1397A, 1397B and 1397C. Ten out of the twelve transgenic families displayed cataracts. We chose to characterize the phenotype in some detail for 4 of the

Fig. 4. Lens histology. Eyes from E12.5 wild-type (WT, A), OVE1397A (B), OVE1462 (C) and OVE1465 (D) transgenic mice, were sectioned and stained with hematoxylin and eosin. Compared to the wild-type lens (A), all the transgenic lenses are bigger and the lens epithelial cells are multi-layered (B-D). The lens transitional zone (t), where epithelial cells begin to differentiate into fiber cells, is not well defined in the transgenic lenses. The anterior epithelial cells in OVE1462 lens are slightly elongated (C). The fiber cells are poorly aligned and incompletely elongated in OVE1462 (C) and 1465 (D) lenses. There are extra nuclei in the fiber cell region, particularly in line OVE1462 and 1465. As a consequence of lens cell hyperplasia, the anterior chamber is displaced in the transgenic eyes. The structure of the anterior retina is also altered as shown in (B) and (C).

families (OVE1397A, 1461, 1462 and 1465). Homozygous 1465 mice were found to develop skin papillomas within 2-3 weeks after birth (data not shown). The Ras transgene mRNA was not detected in the skin papillomas by in situ hybridizations using the riboprobe shown in Fig. 3 (data not shown). We believe this phenotype is due to insertional activation of an endogenous tumor suppressor gene. The skin tumors will be described in detail in a separate publication.

Transgene expression was first examined by in

in situ hybridizations using eyes from different ages. At E11.5, high levels of $\mathrm{N}$-Ras transcripts were detected in the lens vesicle, retina and the surrounding head tissues (Fig. 2). Interestingly, transcription of $\mathrm{N}$-Ras in the lens declined quite rapidly after E13.5. At E15.5, N-Ras mRNA was found in the lens epithelial cells and newly formed fiber cells (Fig. 2F, arrows). By P21, N-Ras expression was barely detectable (Fig. 2I, arrows). Thus, the situ hybridization (Fig. 3B). At E12.5, expression was detected in all lens cells (Fig. 3B), confirming that the chimeric $\delta$ en $\alpha$ A promoter can target transgene expression to both lens epithelial and fiber cells (Reneker et al., 2004). Among the three transgenic families shown, the expression level was OVE1465>OVE1462>OVE1461. No expression of the transgene was detected in the cornea, retina, or other regions of the eye (Fig. 3B)
Fig. 5. Lens changes in transgenic family OVE1462. Histological sections of wild-type $(A, D)$ and OVE1462 transgenicn ( $B, C, E$ and $F)$ eyes at E14.5 (A-C) and E16.5 (D-F) were stained with H\&E. Higher magnification images of $(B)$ and $(E)$ are shown in (C) and (F) respectively. In the wild-type lens (A,D), the cuboidal epithelial cells forma simple monolayer at the anterior surface. In the transgenic lenses $(\mathbf{B}, \mathbf{C}, \mathbf{E}, \mathbf{F})$, the anterior surface epithelial cells (green arrows) are in columnar shape, and some of the cells become detached from the lens capsule and internalized. These cells are dysplastic and disorganized (indicated by the green arrowheads). In contrast to the wild-type lens, which is an avascular tissue, patches of red blood cells were identified in the transgenic lenses after E15.5 (indicated by arrows in (E). Fiber cells in transgeniclens begin to degenerate after E15, leading to microphthalmia at birth.
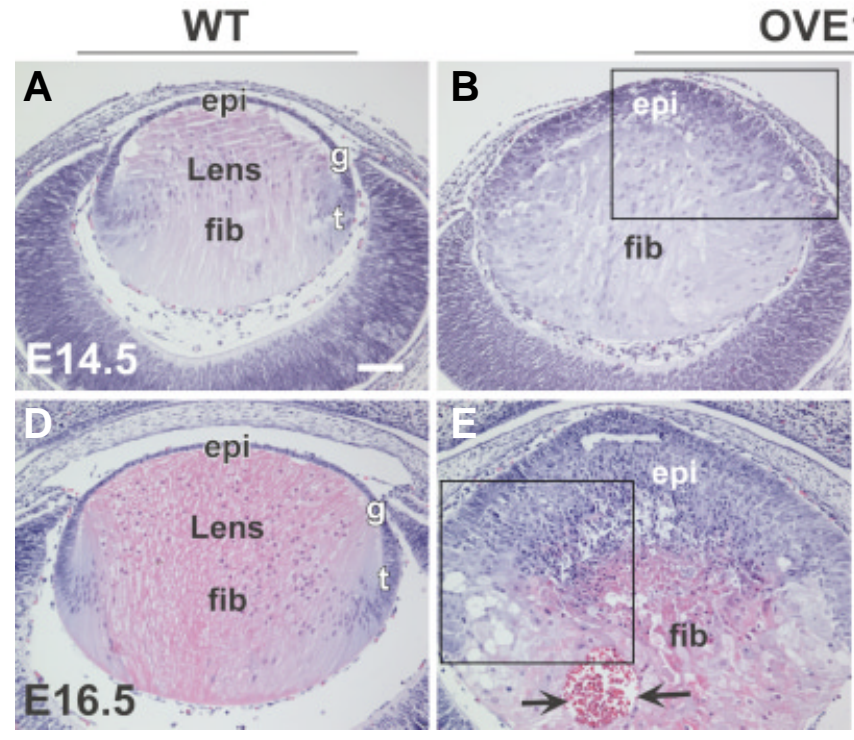
At E12.5, the transgenic lenses were bigger and contained more cells than the non-transgenic lens (Fig. 4). In family OVE1397A, fiber cell elongation was nearly normal at this early stage. The fiber cells in families OVE 1462 and 1465 were already poorly aligned and incompletely elongated. In family 1462 , the epithelial cells were elongated and columnar, rather than their traditional cuboidal shape. In all of the transgenic families, epithelial cells showed evidence of hyperplasia, detachment from the basement membrane, internalization within the lens, and dysplasia. None of the transgenic families showed a phenotype, suggesting that activation of Ras was sufficient to convert the lens epithelial cells into terminally differentiated fiber cells, or into any other cell type.

Prenatal progression of the lens defects was examined in transgenic family 1462 (Fig. 5). Extra cells exhibiting a dysplastic phenotype were always present in the anterior region of the transgenic lenses (green arrowheads in Fig. 5, C and F). In many ways this phenotype is similar to that seen in transgenic mice that express PDGF in the lens (Reneker and Overbeek, 1996). Therefore, the phenotype appears to be caused by excessive proliferation of the lens epithelial cells. The fiber cells in the transgenic lenses were poorly differentiated. They became vacuolated and began to degenerate after E16.5 (Fig. $5)$. The transgenic lenses also became vascularized after E16.5. Islands of red blood cells could be identified in the fiber mass (arrows in Fig. 5E). This phenotype was consistent among the transgenic families although the time of onset varied depending on the level of transgene expression. Histological analysis showed that vascularization of the transgenic lens

Fig. 7. BrdU incorporation in E12.5 and E13.5 lenses. BrdU immunohistochemistry was used to detect cells at the S-phase of the cell cycle. In wild-type lenses (A,C), BrdU positive cells are seen in the lens epithelium, especially at the germinative zone larrows in $A, C)$. Elongated fiber cells do not incorporate BrdU since these cells are postmitotic. In the transgenic lenses (B,D), more BrdU-positive cells are found in the anterior region. Additionally, BrdU-positive cells are present in the posterior region of the transgenic lens (arrows in $B, D$ ).
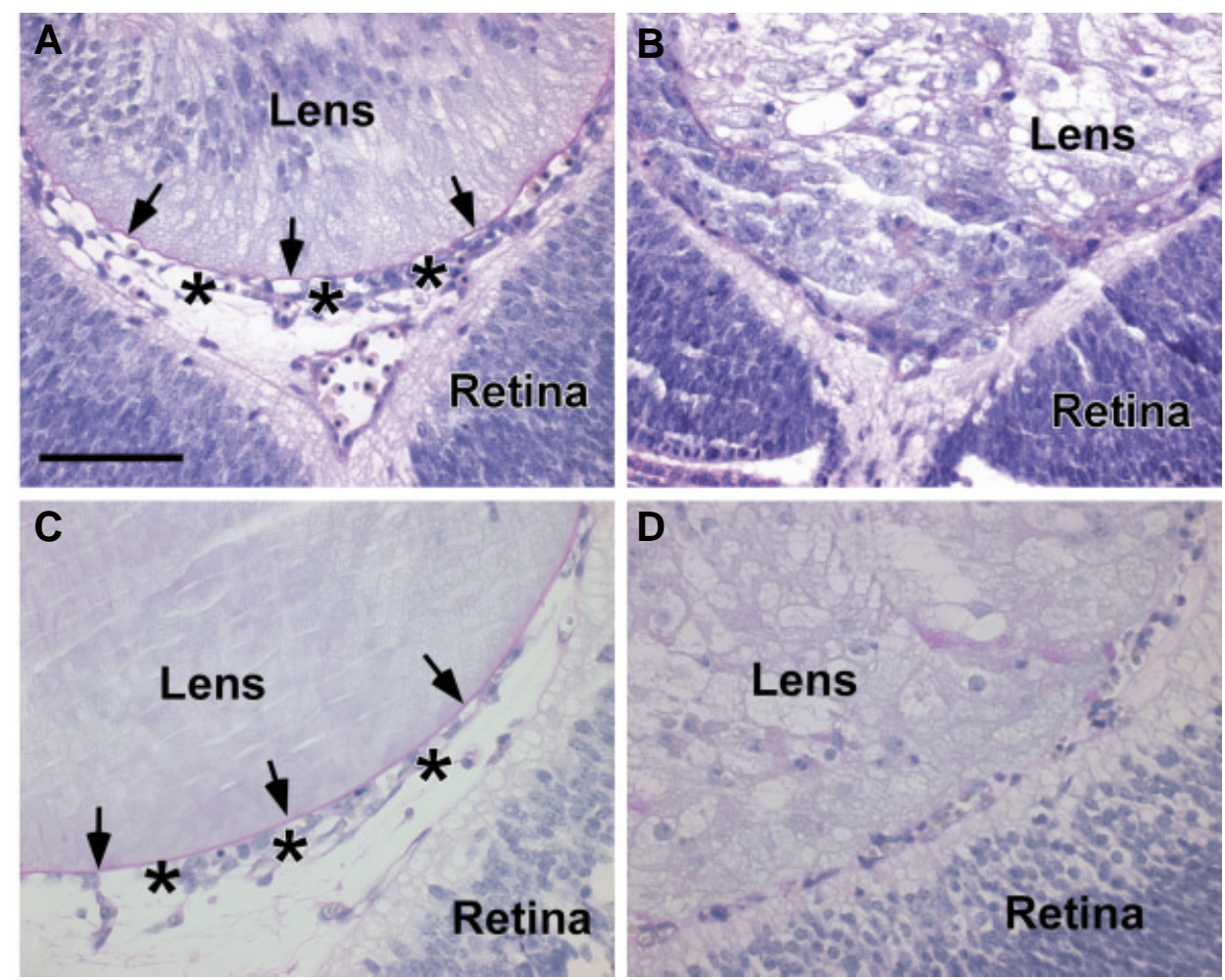

Fig. 6. Disruption of lens capsule in the transgenic eyes. $E 13.5$ (A,B) or E15.5(C,D) eye sections were stained with PAS and then counter-stained with hematoxylin. The lens capsule (purple-red color, indicated by the arrows) is intact in the wild type lens $(A, C)$ but disrupted in the transgenic lens from line OVE1465 (B) or OVE1461 (D).
WT

A
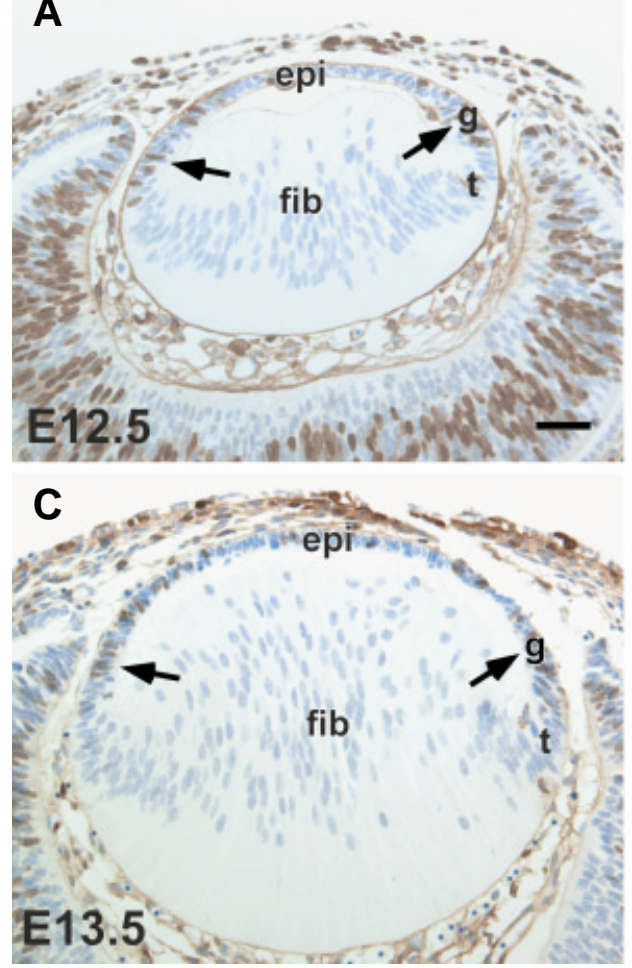

OVE1462

B
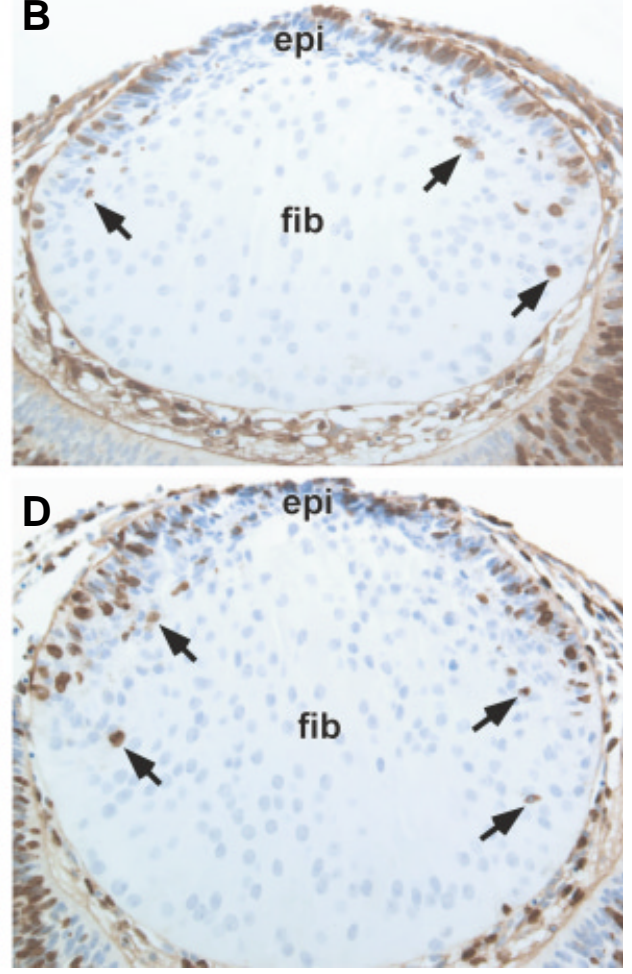


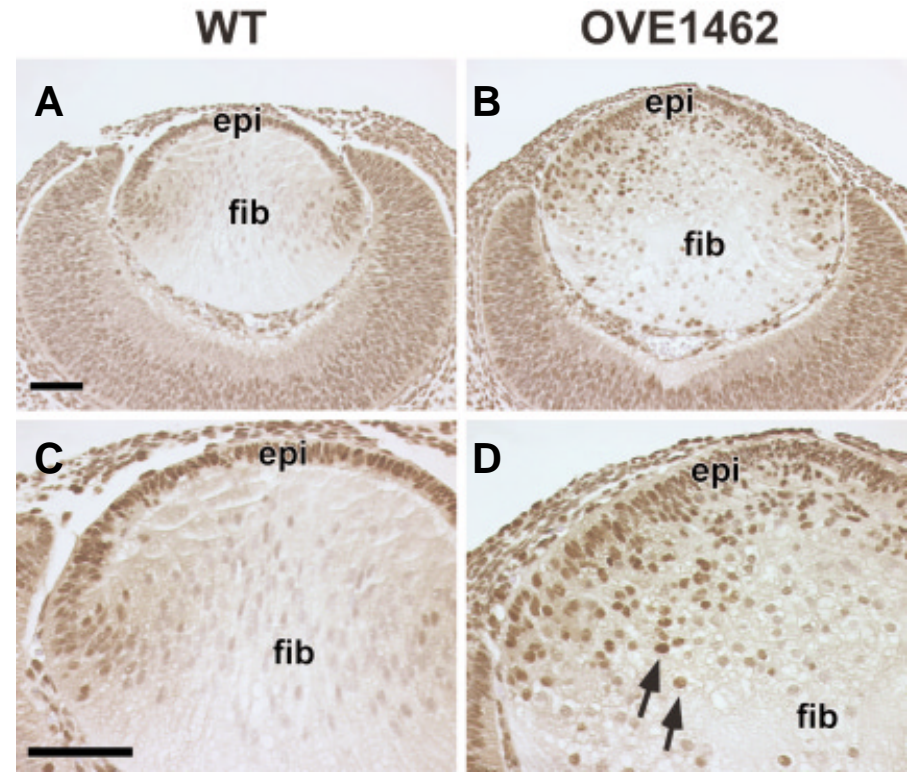

begins with the disruption of the lens capsule and then invasion of the hyaloid vascular cells (Fig. 6).

The increases of lens size and cell number were suggestive of over-proliferation in the transgenic eyes. To test this hypothesis, we assayed for DNA synthesis by BrdU incorporation in E12.5 and E13.5 lenses (Fig. 7). In a normal lens, BrdU-positive cells are found in the lens epithelium (Fig. $7 \mathrm{~A}, \mathrm{C}$ ). At the equatorial zone of the normal lens, cells exit from the cell cycle and commit to differentiation. The posterior fiber cells are postmitotic and $\mathrm{BrdU}$ negative. In the transgenic lenses, BrdUincorporation was seen mostly in the cells at the anterior of the lens, but a few BrdUpositive cells were also found in the fiber cell region (indicated by the arrows in Fig. 7 B,D). We calculated the BrdU labeling index, defined as the number of BrdU-positive cells divided by the total number of cells, in the

Fig. 9. Crystallin expression in E12.5 lenses. Localization of $\alpha$ - $(A$ and $B), \beta-(C$ and $D)$ and $\gamma-(E$ and $F$ ) crystallins (red color) by immunohistochemistry is shown in E12.5 wildtype $(\mathbf{A}, \mathbf{C}, \mathbf{E})$ and OVE1462 transgenic (B,D,F) eyes. DAPI-staining (blue) was used to reveal the cell nuclei in each section. Images of crystallin and nuclear-staining are merged and shown in the figure. In wild-type lens (WT), $\alpha$-crystallin is present in both lens epithelial (indicated by the arrows) and fiber cells (A), while $\beta$-and $\gamma$-crystallins are only found in lens fiber cells (C,E) respectively. Cells at the anterior region of the transgenic lens express $\alpha$-crystallins (B), but not $\beta$ - and $\gamma$ crystallins (D,F) respectively, implying that constitutive activation of Ras is not sufficient to induce premature differentiation in these cells.
Fig. 8. PCNA immunohistochemical staining. E12.5 wild-type (A,C) and OVE1462 transgenic (B,D) eyes were assayed for the expression of PCNA, a cell proliferation marker. Higher magnification images of $(A)$ and $(B)$ are shown in (C) and (D) respectively. In the wild-type lens (A,C), PCNA immunoreactivity (brown nuclear staining) is present in the lens epithelial cells, but not in the mature fiber cell nuclei. In the transgenic lens $(B, D)$, in addition to all the lens epithelial cell nuclei, PCNA staining was also present in many of the fiber cell nuclei, suggesting that constitutive activation of Ras interferes with the normal fiber cell differentiation program.

anterior surface epithelium of the OVE1397A and 1462 lens. The BrdU labeling index was about $27 \%$ in the wild type lens, $63 \%$ in OVE1397A and 55\% in OVE1462 lens, confirming that there is an increase in cell proliferation in the anterior epithelium of the Ras transgenic lens.

The altered pattern of cell cycle regulation in the Ras transgenic lenses was confirmed by assaying for expression of PCNA (proliferating cell nuclear antigen) (Fig. 8). In the normal lens, PCNA is present in the nuclei of the proliferative lens epithelial cells. Expression is turned off in the central fiber cells. PCNApositive fiber cells were present in the transgenic mice, suggesting that unregulated Ras-signaling interferes with normal cell cycle exit during differentiation.

In some of the transgenic families (e.g. OVE1462), the anterior

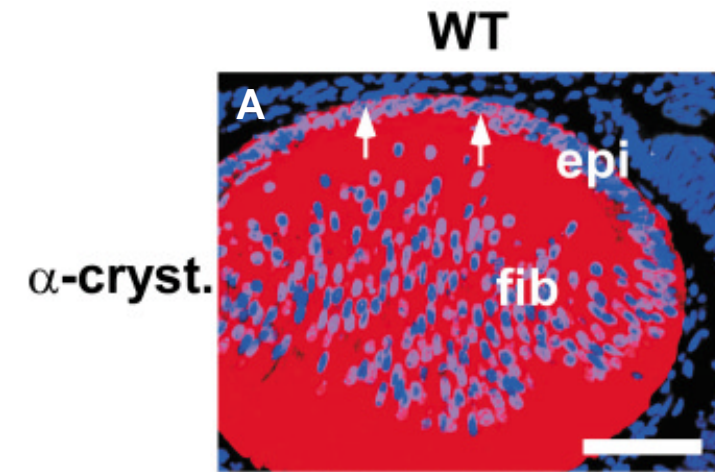

$\beta$-cryst.
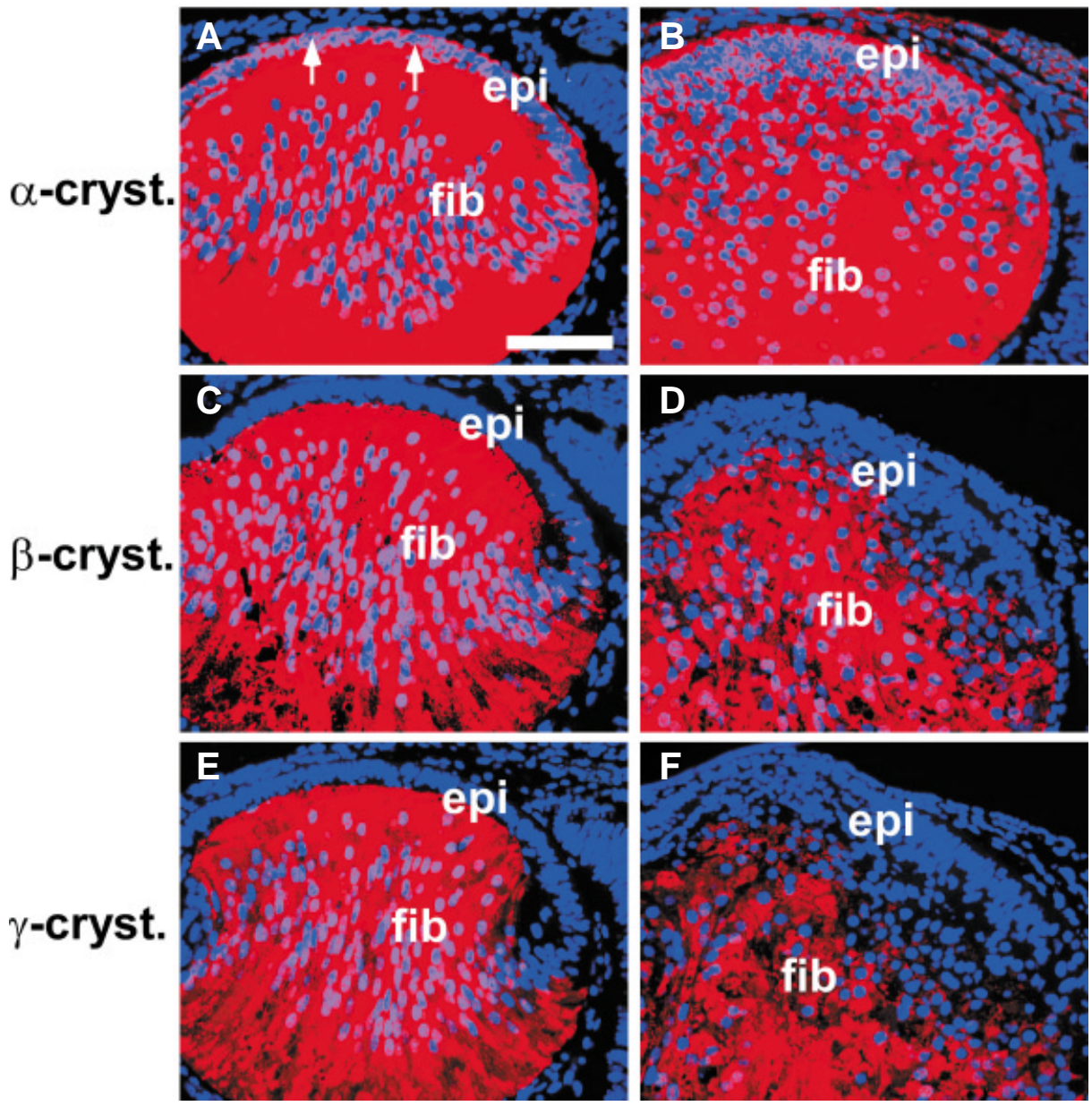

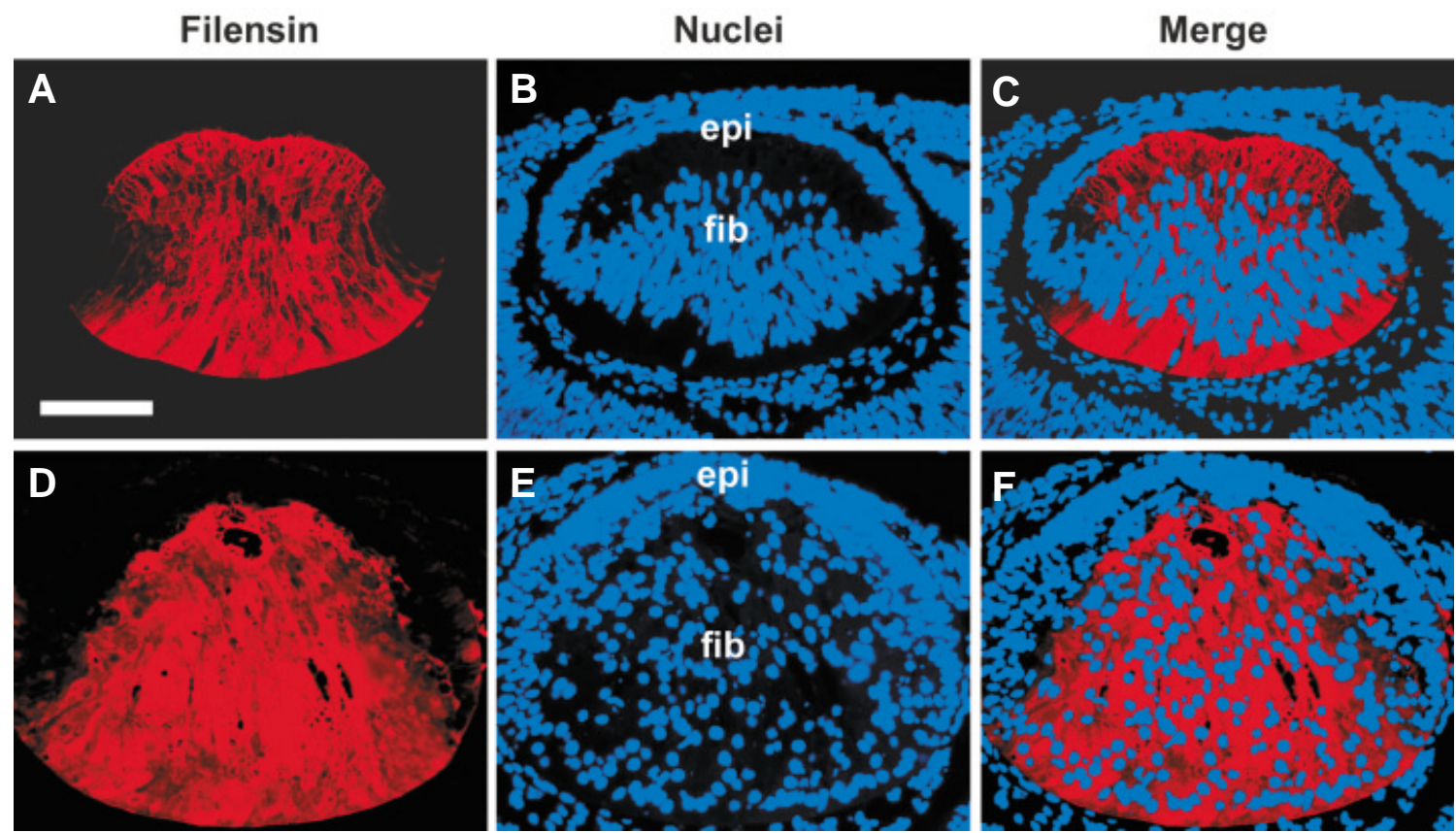

Fig. 10. Expression of filensin in E12.5 lenses. Filensin (red color) was detected by immunohistochemistry (A,D). Cell nuclei (b/ue color) were revealed by DAPI-staining (B,E). Merged images of $(A, B)$ and $(C, D)$ are shown in $(C)$ and (F) respectively. In both wild-type $(A)$ and OVE1462 transgenic (D) lenses, filensin is detected only in the posterior fiber cells.

lens epithelial cells were slightly elongated. To examine whether this reflects a premature differentiation of the lens epithelial cells, we stained for fiber cell specific markers, including $\beta$ - and $\gamma$ crystallins (Fig. 9) as well as filensin (Fig. 10). In the normal E12.5 lens, $\alpha$-crystallin is expressed in both lens epithelial and fiber cells, while $\beta$ - and $\gamma$-crystallins are expressed only in the fiber cells (data not shown). In the transgenic lens, $\alpha$-crystallin was detected in all cells, implying that all of the cells retained their identity as lens cells. $\beta$ - and $\gamma$-crystallin immuno-reactivity was not found in the anterior lens cells, confirming that Ras activation was not sufficient to induce premature differentiation of these cells. We also did immunostaining for filensin, another marker of lens fiber cells (Fig. 10). In both non-transgenic and transgenic mice, filensin was detected only in the lens fiber cells.

\section{Discussion}

\section{Ras genes are expressed in mouse lens during development}

Although the extracellular signals that regulate lens growth have not been identified, previous studies indicate that growth factors are likely candidates (McAvoy et al., 1999). Lens cells express receptors for a variety of growth factors, including FGFs (de longh and McAvoy, 1993), PDGFs (Reneker and Overbeek, 1996), insulin and IGFs (Shirke etal., 2001). Receptors for these growth factors are receptor tyrosine kinases (RTKs). Studies have shown that Ras proteins play essential roles in transmitting signals downstream of RTKs. In many cell types, Ras activation can stimulate proliferation. In some situations, Ras is involved in cellular differentiation (Raucci et al., 2004; Smith et al., 2004). In the present study, we first examined whether specific Ras genes are expressed in the mouse lens during development. Using RTPCR with specific primers, we found that the mouse lens expresses all three classical Ras genes. N-Ras is strongly expressed in the lens at E11.5 and E13.3 (Fig. 1 and 2), but expression decreases quickly after E13.5. After E15.5, the N-Ras mRNA was mostly found in the lens epithelial cells and newly differentiating fiber cells (Fig. 2).

Ras expression has also been detected in the lenses of other species (Zelenka et al., 1989; Andeol et al., 1992; Rao et al., 1997). Surprisingly N-Ras expression was not found in primary embryonic chick lens tissue (Zelenka et al., 1989). It is possible that different Ras genes are preferentially expressed in the lenses of different species.

\section{Constitutively active Ras induces lens cell proliferation but not differentiation}

Since growth factors can stimulate either proliferation or differentiation of lens epithelial cells, we hypothesized that Ras activation might be critical for either cell proliferation or differentiation. To assess the consequences of Ras activation in lens cells, we generated transgenic mice expressing a constitutively active mutant $\mathrm{H}$-Ras in all cells of the lens. Transgene expression induced hyperplasia, but not premature differentiation, of the lens epithelial cells. At E12.5, Ras-transgenic lenses were bigger and contained extra cells, rather than fewer cells (Fig. 4). The anterior cells did not elongate as seen in FGF-overexpressing lenses (Robinson et al., 1995b; Robinson et al., 1998), nor did they exit from the cell cycle. Instead, BrdU incorporation assays showed that there was a two-fold increase of S-phase cells in the Rastransgenic lenses when compared to nontransgenic lenses (Fig. 7). Immunostaining for $\beta$ - and $\gamma$-crystallins, and for filensin, showed that the anterior cells were not induced to express these fiber cell-specific markers (Fig. 9 and 10). Therefore, we conclude that activation of $\mathrm{H}$-Ras is not sufficient to stimulate lens cell differentiation. Lens cell differentiation apparently requires activation of alternative signal transduction pathways. In contrast, 
expression of activated $\mathrm{H}$-Ras is sufficient to convert retinal pigment epithelial cells to a neuronal differentiation program (Zhao et al., 2001).

It is perhaps worth stressing that normal lens cells express higher levels of $\mathrm{N}$-Ras than $\mathrm{H}$ - and K-Ras. The constitutively active Ras expressed in the transgenic lenses is an H-Ras mutant. It is certainly possible that $\mathrm{H}$ - and $\mathrm{N}$-Ras can mediate different cellular responses. Although the classical Ras genes are thought to activate the same downstream effectors including Raf1 and phosphoinositol 3-kinase (PI3K), they may do so with different efficiencies. At this time we cannot rule out the possibility that $\mathrm{N}$-Ras and $\mathrm{H}$-Ras activate different responses in lens epithelial cells.

Previous studies using rat lens explants showed that PDGF and low doses of FGF can stimulate lens epithelial cell to proliferate while higher doses of FGF induce premature differentiation of these cells (McAvoy and Chamberlain, 1989; Kok et al., 2002). In transgenic mice, PDGF acts as an epithelial cell mitogen while FGFs induce differentiation (Robinson et al., 1995b; Reneker and Overbeek, 1996). The receptors for both growth factors are receptor tyrosine kinases (RTKs) that can activate Ras-mediated signaling pathways including the Raf/MEK/ERK pathway. During lens development, the phosphorylated (or active) forms of ERK are present in both lens epithelial and fiber cells (Lovicu and McAvoy, 2001). In our transgenic mice, constitutive activation of Ras should lead to prolonged ERK activation. The fact that activated Ras does not induce premature differentiation of lens epithelial cells implies that prolonged activation of ERKs is not sufficient to initiate fiber cell differentiation. Instead, our studies show that elevated Ras activity inhibits normal fiber cell differentiation. For example, BrdU positive fiber cells are seen in the transgenic lenses (Fig. 7), and the fiber cells do not elongate normally. Additionally, PCNA-positive cells are found in the region where cells are normally postmitotic (Fig. 8). The inhibition of cell cycle exit is not yet understood, but may reflect loss of p57 expression or function (Zhang et al., 1998).

There are several other possibilities to explain the different outcome of PDGF- and FGF-stimulation in the lens epithelial cells: 1) PDGF and FGF activate different subsets of signal transduction pathways in addition to the common Ras/ERK pathways and/or 2) Different adaptor and/or modulator proteins may lead to divergent signaling mechanisms. For example, a key component of FGF signaling is the docking protein, FRS2, which binds to the FGF receptors but not PDGF receptors (Ong et al., 2001). Similarly, Sprouty and Sef proteins act as negative regulators of FGFR (Hanafusa et al., 2002; Preger et al., 2004), but these proteins have not been shown to interact with PDGF receptors. Whether FRS, Sprouty and Sef play a role in lens development is an open question for further investigation.

\section{Prolonged activation of Ras results in rupture of the lens capsule}

The active Ras mutant we used in this study was highly transforming in cell culture (Reynolds et al., 1987). Here we demonstrate that this mutant can induce hyperproliferation of lens epithelial cells (Fig. 4) and can disrupt the normal cell cycle exit that occurs during fiber cell differentiation (Fig. 7 and 8). In addition, the posterior lens capsule begins to degenerate, and the fiber cells become vacuolated (Fig. 6). This sequence of events was seen in all three transgenic families (OVE1461, 1462 and 1465) we examined. Blood islands are subsequently found within the lens. A previous study showed that activation of the Raf/MAP kinase pathway can upregulate the expression of angiogenic factors, such as VEGF and FGF2 (Schulze et al., 2001). Whether such a mechanism also applies in the Ras-transgenic eye is currently under investigation.

In summary, we show that embryonic mouse lens cells express Ras genes, mainly N-Ras. Expression levels change as the lens grows. Downregulation of $\mathrm{N}$-Ras coincides with a reduction in lens growth rate, suggesting that $\mathrm{N}$-Ras may play a role in lens cell growth. Expression of a constitutive active $\mathrm{H}$-Ras protein in the lens induces hyperplasia, but not premature differentiation, of the lens epithelial cells. Alternative signal transduction pathways are therefore predicted to be essential for the induction of fiber cell differentiation.

\section{Materials and Methods}

\section{Preparation of riboprobe plasmids and in situ hybridization}

To assay for expression of different Ras genes in the lens, total RNA was isolated from newborn FVB/N mouse lenses using RNA Stat-60 (Teltest"B", Inc., Friendwood, Texas) and subjected to a reverse-transcription reaction (RT) using random primers (Promega) and Superscript II reverse transcriptase (Invitrogen, Life Technologies). The following primers were used to amplify specific Ras transcripts (Barbacid, 1987):

5' - CGCGGATCCCAGCTGATCCAGAACCACTTTGTGG-3'(sense) and 5' -CGCGAATTCTCACACTTGTTGCCTACCAG-3'(antisense) for H-Ras, 5'-CGC GGATCCCAGCTAATTCAGAATCACTTTGTGG-3'(sense) and 5'-CGCGAATTCTCACACTTGTTCCCAACCAG-3' (antisense) for K-Ras, and 5'-CGCGGATCCCAGCTAATCCAGACCACTTTGTGG-3' (sense) and 5'-CGCGAATTCTCACACTTGTTGCCTACCAG-3' (antisense) for $\mathrm{N}$-Ras. The underlined sequences in the sense and antisense primers are restriction enzyme sites. After amplification by polymerase chain reaction (PCR) and fractionation by agarose gel electrophoresis, bands were excised and digested with BamHI and EcoRI, then inserted into pBluescriptSK and sequenced. To generate riboprobes for in situ hybridizations, plasmids were linearized by restriction enzyme digestion. ${ }^{35}$ S-labeled riboprobes were prepared using T3 or T7 RNA polymerase and an in vitro transcription kit (Promega). Embryonic heads or postnatal eyes were fixed in $10 \%$ neutral-buffered formalin, processed and embedded in paraffin. Sections at $5 \mu \mathrm{m}$ were mounted on Superfrost Plus (Fisher Scientific) glass slides and used for in situ hybridization as described previously (Xu et al., 2002). After washing, slides were coated with NTB2 emulsion (Kodak), exposed for about a week at $4^{\circ} \mathrm{C}$, developed with Kodak D-19 developer and then counter stained with hematoxylin. Slides were visualized using a Leica DMR microscope and images were captured by a CCD camera.

To detect expression of the Ras transgene in the eye, the human growth hormone (hGH) sequences used to make the minigene (Fig. 3) were cloned into pBluescript-SK and used to generate a riboprobe.

\section{Generation of transgenic mice}

The mouse $\alpha$ A-crystallin promoter was modified by adding a chick $\delta 1$ crystallin enhancer element to the 5' end of the promoter (Reneker et al., 2004). This modified $\alpha A$-crystallin promoter can target transgene expression to both lens epithelial and fiber cells (Reneker et al., 2004). The last intron and polyadenylation signal from the human growth hormone gene $(\mathrm{hGH})$ were added to the 3 ' end of the $\alpha$ A-crystallin promoter (Seeburg, 1982). A human genomic clone (rasT24) containing the coding region of an activated (oncogenic) H-Ras (H-RasV12) gene (from Dr. Michael Lieberman, Baylor College of Medicine) (Reynolds et al., 1987) was inserted downstream of the $\alpha$ A-promoter and upstream of 
the hGH sequences. The resultant plasmid was digested with Xhol and Sacll and the DNA fragment was separated by electrophoresis on a $1 \%$ agarose gel. The $4.3 \mathrm{~kb}$ microinjection fragment (Figure 3A) was isolated from the gel and purified using a Qiaexll gel extraction kit (Qiagen). Transgenic mice were generated by pronuclear injection of the purified DNA fragment into one-cell-stage inbred FVB/N embryos. Potential transgenic mice were identified by PCR on tail DNA using primers homologous to the hGH portion of the transgene (Fig. 3A) (sense, 5'ATCTGCAGTTCCTCAGGAGTGTCTTC3', and antisense 5'AGACTAGTTGAGCCTGGTCATGCATG3').

\section{Histological analysis}

For routine histology, embryos were obtained from timed pregnancies using $\mathrm{FVB} / \mathrm{N}$ females mated to either heterozygous or homozygous transgenic males. Embryonic heads were removed and fixed overnight in $10 \%$ neutral-buffered formalin. Tissues were dehydrated, embedded in paraffin, sectioned at $5 \mu \mathrm{m}$ and stained with hematoxylin and eosin (H\&E). To reveal the lens capsule, sections were stained with PAS and then counter-stained with hematoxylin.

\section{BrdU incorporation}

For detection of cells at the S-phase of the cell cycle, pregnant females were injected intraperitoneally with 5-bromo-2'-deoxyuridine (BrdU, Sigma, St. Louis) at a concentration of $100 \mu \mathrm{g} / \mathrm{gram}$ of body weight. After one hour, the pregnant mice were sacrificed and embryos were processed to detect BrdU incorporation by immunohistochemistry as described below.

\section{Immunohistochemistry}

Tissue sections were first de-waxed with xylene, rehydrated with ethanol, and then blocked by incubation with $5 \%$ non-immune serum in phosphate buffered saline (PBS) at room temperature for 30 minutes. Primary antibodies against BrdU (Dako, Carpinteria, CA) and proliferating cell nuclear antigen (PCNA) (Zymed, San Francisco, CA) were diluted $1: 100$ and $1: 200$ respectively in PBS solution containing $2 \%$ serum. Primary antibodies against crystallins $(\alpha-, \beta$ - and $\gamma-$ ) and filensin were provided by Dr. Samuel Zigler (National Eye Institute, Bethesda, MD) and Dr. Roy Quinlan (the University Medical Science institute, Dundee, Scotland) respectively and used with the following dilutions: $\alpha$-crystallin (1:500), $\beta$-crystallin (1:1000), $\gamma$-crystallin (1:2000), and filensin $(1: 100)$. Sections were incubated with a primary antibody overnight at $4^{\circ} \mathrm{C}$. After rinsing with PBS, sections were incubated with either biotinylated (Vector Laboratories) or fluorescein-conjugated (Molecular Probe) secondary antibodies at room temperature for 1 hour. For BrdU and PCNA immunostaining, avidin-biotin-peroxidase detection was done using DAB as a substrate and following the manufacturer's protocol (Vector Laboratories). For $\alpha-, \beta-, \gamma$-crystallins and filensin immunostaining, slides were rinsed with PBS and then mounted with cover slips in $50 \%$ glycerol in PBS for examination under UV illumination.

\section{Acknowledgements}

We thank Michael Lieberman for the H-Ras clone, Sam Zigler for the anti- $\alpha$-, $\beta$ - and $\gamma$-crystallin antibodies, and Roy Quinlan for the filensin antibody. We thank Gaby Schuster for generating the Ras transgenic mice and Shanyu Ho for technical support. We thank Ms. Sharon Morey for editing and proofreading of the manuscript. This work was supported by NIH grants EY13146 (LWR) and EY10448 (PAO), and a NIH core grant EY14795, and by departmental unrestricted funds from Research to Prevent Blindness (RPB) Inc. (LWR).

\section{References}

ANDEOL, Y., MECHALI, M., and HOURDRY, J. (1992). Localization of ras protooncogene expression during development in Xenopus laevis. Mol. Reprod. Dev. 32: 187-95.
BARBACID, M. (1987). ras genes. Annu. Rev. Biochem. 56: 779-827.

CAMPBELL, S. L., KHOSRAVI-FAR, R., ROSSMAN, K. L., CLARK, G. J., and DER, C. J. (1998). Increasing complexity of Ras signaling. Oncogene 17: 1395-413.

CHAMBERLAIN, C. G., and MCAVOY, J. W. (1989). Induction of lens fibre differentiation by acidic and basic fibroblast growth factor (FGF). Growth Factors 1: 125-34.

CHAMBERLAIN, C. G., MCAVOY, J. W., and RICHARDSON, N. A. (1991). The effects of insulin and basic fibroblast growth factor on fibre differentiation in rat lens epithelial explants. Growth Factors 4: 183-8.

CHOW, R. L., and LANG, R. A. (2001). Early eye development in vertebrates. Annu. Rev. Cell Dev. Biol. 17: 255-96.

CHOW, R. L., ROUX, G. D., ROGHANI, M., PALMER, M. A., RIFKIN, D. B., MOSCATELLI, D. A., and LANG, R. A. (1995). FGF suppresses apoptosis and induces differentiation of fibre cells in the mouse lens. Development121: 438393.

CVEKL, A., and PIATIGORSKY, J. (1996). Lens development and crystallin gene expression: many roles for Pax-6. Bioessays 18: 621-30.

DE IONGH, R., and MCAVOY, J. W. (1993). Spatio-temporal distribution of acidic and basic FGF indicates a role for FGF in rat lens morphogenesis. Dev. Dyn. 198: 190-202.

DE IONGH, R. U., LOVICU, F. J., CHAMBERLAIN, C. G., and MCAVOY, J. W. (1997). Differential expression of fibroblast growth factor receptors during rat lens morphogenesis and growth. Invest. Ophthalmol. Vis. Sci. 38: 1688-99.

DE IONGH, R. U., LOVICU, F. J., HANNEKEN, A., BAIRD, A., and MCAVOY, J. W. (1996). FGF receptor-1 (flg) expression is correlated with fibre differentiation during rat lens morphogenesis and growth. Dev. Dyn. 206: 412-26.

DOWNWARD, J. (2003). Targeting RAS signalling pathways in cancer therapy. Nature Reviews Cancer 3: 11-22.

GOVINDARAJAN, V., and OVERBEEK, P. A. (2001). Secreted FGFR3, but not FGFR1, inhibits lens fiber differentiation. Development 128: 1617-1627.

HANAFUSA, H., TORII, S., YASUNAGA, T., and NISHIDA, E. (2002). Sprouty1 and Sprouty2 provide a control mechanism for the Ras/MAPK signalling pathway. Nat. Cell Biol. 4: 850-8.

HAYASHI, S., GOTO, K., OKADA, T. S., and KONDOH, H. (1987). Lens-specific enhancer in the third intron regulates expression of the chicken delta 1-crystallin gene. Genes Dev. 1: 818-28.

HELDIN, C. H. (1995). Dimerization of cell surface receptors in signal transduction. Cel/ 80: 213-23.

HYATT, G. A., and BEEBE, D. C. (1993). Regulation of lens cell growth and polarity by an embryo-specific growth factor and by inhibitors of lens cell proliferation and differentiation. Development 117: 701-9.

JEAN, D., EWAN, K., and GRUSS, P. (1998). Molecular regulators involved in vertebrate eye development. Mech. Dev. 76: 3-18.

KOK, A., LOVICU, F. J., CHAMBERLAIN, C. G., and MCAVOY, J. W. (2002). Influence of platelet-derived growth factor on lens epithelial cell proliferation and differentiation. Growth Factors 20: 27-34.

LE, A. C., and MUSIL, L. S. (2001). FGF signaling in chick lens development. Dev. Biol. 233: 394-411.

LOVICU, F. J., and MCAVOY, J. W. (2001). FGF-induced lens cell proliferation and differentiation is dependent on MAPK (ERK1/2) signalling. Development 128: 5075-84.

LOVICU, F. J., and OVERBEEK, P. A. (1998). Overlapping effects of different members of the FGF family on lens fiber differentiation in transgenic mice. Development 125: 3365-77.

MAIDMENT, J. M., DUNCAN, G., TAMIYA, S., COLLISON, D. J., WANG, L., and WORMSTONE, I. M. (2004). Regional differences in tyrosine kinase receptor signaling components determine differential growth patterns in the human lens. Invest. Ophthalmol. Vis. Sci. 45: 1427-35.

MCAVOY, J. W., and CHAMBERLAIN, C. G. (1989). Fibroblast growth factor (FGF) induces different responses in lens epithelial cells depending on its concentration. Development 107: 221-8.

MCAVOY, J. W., CHAMBERLAIN, C. G., DE IONGH, R. U., HALES, A. M., and LOVICU, F. J. (1999). Lens development. Eye. 13: 425-437.

MENKO, A. S. (2002). Lens epithelial cell differentiation. Exp. Eye Res. 75: 485-90. 
MORRISON-GRAHAM, K., SCHATTEMAN, G. C., BORK, T., BOWEN-POPE, D. F., and WESTON, J. A. (1992). A PDGF receptor mutation in the mouse (Patch) perturbs the development of a non-neuronal subset of neural crest-derived cells. Development 115: 133-42.

ONG, S. H., HADARI, Y. R., GOTOH, N., GUY, G. R., SCHLESSINGER, J., and LAX, I. (2001). Stimulation of phosphatidylinositol 3-kinase by fibroblast growth factor receptors is mediated by coordinated recruitment of multiple docking proteins. Proc. Natl. Acad. Sci. USA 98: 6074-9.

PIATIGORSKY, J. (1981). Lens differentiation in vertebrates. A review of cellular and molecular features. Differentiation 19: 134-53.

POTTS, J. D., BASSNETT, S., KORNACKER, S., and BEEBE, D. C. (1994). Expression of platelet-derived growth factor receptors in the developing chicken lens. Invest. Ophthalmol. Vis. Sci. 35: 3413-21.

PREGER, E., ZIV, I., SHABTAY, A., SHER, I., TSANG, M., DAWID, I. B., ALTUVIA, Y., and RON, D. (2004). Alternative splicing generates an isoform of the human Sef gene with altered subcellular localization and specificity. Proc. Nat/. Acad. Sci. USA 101: 1229-34.

RAO, P. V., ZIGLER, J. S., JR., and GARLAND, D. (1997). Analysis of small GTPbinding proteins of the lens by GTP overlay assay reveals the presence of unique GTP-binding proteins associated with fiber cells. Exp. Eye Res. 64: 219-27.

RAUCCI, A., LAPLANTINE, E., MANSUKHANI, A., and BASILICO, C. (2004). Activation of the ERK1/2 and p38 mitogen-activated protein kinase pathways mediates fibroblast growth factor-induced growth arrest of chondrocytes. J. Biol. Chem. 279: 1747-56.

RENEKER, L. W., CHEN, Q., BLOCH, A., XIE, L., SCHUSTER, G., and OVERBEEK, P. A. (2004). Chick delta1-crystallin enhancer influences mouse alphaA-crystallin promoter activity in transgenic mice. Invest. Ophthalmol. Vis. Sci. In press.

RENEKER, L. W., and OVERBEEK, P. A. (1996). Lens-specific expression of PDGF-A alters lens growth and development. Dev. Biol. 180: 554-65.

REYNOLDS, V. L., LEBOVITZ, R. M., WARREN, S., HAWLEY, T. S., GODWIN, A K., and LIEBERMAN, M. W. (1987). Regulation of a metallothionein-rasT24 fusion gene by zinc results in graded alterations in cell morphology and growth. Oncogene 1: 323-30.

RICHARDSON, N. A., CHAMBERLAIN, C. G., and MCAVOY, J. W. (1993). IGF-1 enhancement of FGF-induced lens fiber differentiation in rats of different ages. Invest. Ophthalmol. Vis. Sci. 34: 3303-12.

ROBINSON, M. L., MACMILLAN-CROW, L. A., THOMPSON, J. A., and OVERBEEK, P. A. (1995a). Expression of a truncated FGF receptor results in defective lens development in transgenic mice. Development 121: 3959-67.
ROBINSON, M. L., OHTAKA-MARUYAMA, C., CHAN, C. C., JAMIESON, S., DICKSON, C., OVERBEEK, P. A., and CHEPELINSKY, A. B. (1998). Disregulation of ocular morphogenesis by lens-specific expression of FGF-3/ int-2 in transgenic mice. Dev. Biol. 198: 13-31.

ROBINSON, M. L., OVERBEEK, P. A., VERRAN, D. J., GRIZZLE, W. E., STOCKARD, C. R., FRIESEL, R., MACIAG, T., and THOMPSON, J. A. (1995b). Extracellular FGF-1 acts as a lens differentiation factor in transgenic mice. Development 121 : 505-14.

SCHULZE, A., LEHMANN, K., JEFFERIES, H. B., MCMAHON, M., and DOWNWARD, J. (2001). Analysis of the transcriptional program induced by Raf in epithelial cells. Genes Dev. 15: 981-94.

SEEBURG, P. H. (1982). The human growth hormone gene family: nucleotide sequences show recent divergence and predict a new polypeptide hormone. DNA 1: 239-49.

SHIRKE, S., FABER, S. C., HALLEM, E., MAKARENKOVA, H. P., ROBINSON, M. L., OVERBEEK, P. A., and LANG, R. A. (2001). Misexpression of IGF-I in the mouse lens expands the transitional zone and perturbs lens polarization. Mech Dev101: 167-174.

SMITH, E. R., SMEDBERG, J. L., RULA, M. E., and XU, X. X. (2004). Regulation of Ras-MAPK pathway mitogenic activity by restricting nuclear entry of activated MAPK in endoderm differentiation of embryonic carcinoma and stem cells. J. Cell Biol. 164: 689-99.

STOLEN, C. M., and GRIEP, A. E. (2000). Disruption of lens fiber cell differentiation and survival at multiple stages by region-specific expression of truncated FGF receptors. Dev. Biol. 217: 205-20.

ULLRICH, A., and SCHLESSINGER, J. (1990). Signal transduction by receptors with tyrosine kinase activity. Cel/61: 203-12.

XU, L., OVERBEEK, P. A., and RENEKER, L. W. (2002). Systematic analysis of E, N- and P-cadherin expression in mouse eye development. Exp. Eye Res. 74: 753-60.

ZELENKA, P. S., PALLANSCH, L. A., and VATAL, M. (1989). Nuclear run-on transcription from primary embryonic lens tissue. Dev. Biol. 132: 69-72.

ZHANG, P., WONG, C., DEPINHO, R. A., HARPER, J. W., and ELLEDGE, S. J. (1998). Cooperation between the Cdk inhibitors p27(KIP1) and p57(KIP2) in the control of tissue growth and development. Genes Dev. 12: 3162-7.

ZHAO, S., HUNG, F. C., COLVIN, J. S., WHITE, A., DAI, W., LOVICU, F. J., ORNITZ, D. M., and OVERBEEK, P. A. (2001). Patterning the optic neuroepithelium by FGF signaling and Ras activation. Development128: 505160. 